\title{
Is Elan a turnaround?
}

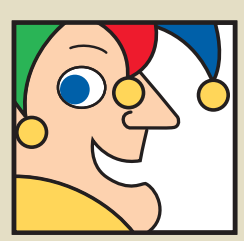

Tom Jacobs, a writer and senior analyst at the Motley Fool (http://www.fool.com/), provides his angle on biotechnology investments. He welcomes your comments at TomJ@Fool.com, but cannot give individual investment advice. He owns no shares of companies mentioned in this month's column.

Kudos to embattled Ireland-based drugmaker Elan (Dublin; NYSE:ELN). Saddled with the financial shenanigans of booted managers (Nat. Biotechnol. 20, 429, 2002), in July 2002 the company said it would 'create a new Elan' and implement a recovery plan to become EBITDA (earnings before interest, taxes, depreciation and amortization)-positive by the end of 2003. It's made enormous progress. But is it a business turnaround worthy of investment?

A typical turnaround involves a sleepy or poorly run business that hires new management to improve financial management, existing product lines and marketing. This is rare in biotech. Although management can raise cash, determine which research to pursue, and strike favorable deals, the best managers can't make a profitable company out of failed drugs, and even the worst may not kill a company with promising candidates or successful drugs on the market.

Ditto Elan. New management has so far fulfilled the recovery plan's goal to sell off key assets_-drug products or shares of them, ownership of other companies - to pay debt that is due now or soon. But even if, as it appears now, the new team were to keep Elan from bankruptcy in the next few years, the future for investors depends on its drugs.

\section{The SEC caveat}

It depends on two other things. Because Elan missed the June 30 filing deadline for its annual report with the US Securities \& Exchange Commission (SEC; Washington, DC, USA), it risks default on some of its debt. The company said that the earnings restatement it's discussing with the SEC would reduce 2001 earnings by $16 \%$ and its 2002 loss by $2.5 \%$. Not desirable, but not a big deal. The creditors will likely forebear, and the annual report will sally forth at some point. But the likely result will be immaterial company earnings restatements, creditor forebearance, and the annual report soon after. Not serious.

The SEC's separate enforcement investigation may draw penalties and trouble for previous management, but I doubt that SEC action alone will kill a company whose new management has been entirely transparent, cooperative, and acting in creditor and shareholder. Enron (Houston, TX, USA) did none of these and died. Tyco International (Portsmouth, NH, USA; NYSE:TYC) so far has done all and escaped death. I'll put Elan with Tyco and take my licks if time proves me wrong.

\section{Cash \& debt}

First, let's examine Elan's cash and debt (see Table 1). Without the June quarter company numbers, we must take the first quarter and estimate from information publicly released since then.

${ }^{*}$ Nature Biotechnology does not guarantee the veracity, reliability, or completeness of any information provided on this page; it is not responsible for any errors or omissions or for any results obtained from the use of such information; it will not be liable for any loss, damage, or investment decision arising from a reader's reliance on the information provided.
Elan sported some debt, but collected $\$ 452.5$ million net from selling certain drugs and stocks. Subtracting the company's $\$ 100$ million average quarterly cash consumption over the past five quarters leaves $\$ 1.42$ billion. That doesn't cover the entire $\$ 2.36$ billion in contracted debt, and with $\$ 100$ million a quarter in burn, it won't satisfy the $\$ 1.27$ billion due in the next two years.

Or will it? The company can pay holders of the $\$ 494$ million in LYONs (liquid option yield notes) in either cash or stock. That would reduce Elan's needs over the next two years to a $\$ 776$ million. Beyond that, the $7.25 \%$ senior debt due 2008 is less of a worry. By then, the company will either be profitable and able to refinance or have far worse problems.

\section{The products}

Fine. But what about the drugs? Having cut expenses to the bone, Elan must increase sales. Retained products raked in $\$ 150$ million in the first quarter, but none currently has the prospects to put a dent in the $\$ 100$ million-a-quarter in cash burn.

Elan's hopes clearly rest on its pipeline. Although the company wants Food and Drug Administration (Rockville, MD, USA) approval next year of pain treatment Prialt (ziconotide, an omega conotoxin MVIIA from the mollusc Conus magus) and revenues thereafter, its best prospect for significant revenues over the next few years is its Antegren (natalizumab) collaboration with Biogen (Cambridge, MA, USA; NASDAQ:BGEN) for the large markets of Crohn's disease and multiple sclerosis. In July, Elan and Biogen announced that Antegren did not meet its primary clinical endpoints in a phase 3 trial for Crohn's, and both companies hope for more positive results against multiple sclerosis.

\section{The bottom line}

Conservative investors understandably shun this stock that nevertheless may intrigue turnaround investors. Current cash and retained product revenue may fund debt and research and development for a few years, but investor rewards depend on Antegren. And because Elan would share revenues with Biogen, Antegren needs to be big.

Whatever the strengths of Elan's remaining pipeline and alliances-its Alzheimer's program with Wyeth (Madison, NJ, USA; NYSE:WYE), for example — it's ironic that after all of former management's aggressive (or worse) accounting designed to build a major drug company in record time, Elan is now arguably like a new biotech, depending on one major drug hopeful to bring real rewards.

\begin{tabular}{lcccr} 
Table 1 Forever in your debt? Elan's present obligations & \\
& \multicolumn{2}{c}{ When due (\$ millions) } & \\
\cline { 2 - 4 } Type of debt & 2003 & 2004 & After & Total \\
\hline Contracted & & & & \\
7.25\% senior notes & - & - & 650 (in 2008) & 650 \\
Fixed product payments & 160 & 78 & 40 & 278 \\
Contingent product payments & 59 & 29 & 14 & 102 \\
EPIL II \& III & - & 450 & 390 & 840 \\
3.25\% LYONS & 494 & - & - & 494 \\
Potential & & & & 110 \\
Pharma marketing & 225 & - & 48 & 335 \\
Product acquisitions & - & - & 1,252 & 48 \\
\hline Total & 938 & 557 & 2,747 \\
\hline aElan Pharmaceutical Investments II (EPIL II); Elan Pharmaceutical Investments III (EPIL III)
\end{tabular}

